\title{
Portrait of Adolescence in the Novels of Ruskin Bond
}

\author{
Revathy M , and DR. Aruna Arputhamalar \\ A \\ Research Scholar, Vel Tech Rangarajan Dr. Sagunthala R\&D Institute of Science \\ and Technolgy Avadi, Chennai \\ ${ }^{\mathbf{b}}$ Research Supervisor, Vel Tech Rangarajan Dr. Sagunthala R\&D Institute of \\ Science and Technolgy, Avadi, Chennai.
}

Article History: Received: 11 January 2021; Accepted: 27 February 2021; Published online: 5 April 2021

\begin{abstract}
Indian English Novel has occupied a significant place at worldwide level. Many well-known writers present the Indian life style and voiced for the social issues in their novels. Ruskin Bond is one among the very few writers who has contributed to the development of children and youngsters. Bond's literary world depicts the adolescents of real life. Bond portrays the journey of innocence to experience in his novels. Bond started writing his first novel when he was an adolescent. The autobiographical part in Bond's novels realistically expresses the growth of an individual from childhood to adolescence. Rather than external factors, Bond puts effort to bring out the mind-set of the adolescents. His lead characters in the novels are in adolescence phase. The novels of Bond has two layers, one which explores everyday life and the other which actually reveals the human psyche. The present paper focuses on the representation of adolescents in the novels of Ruskin Bond. It introspects the characteristics of the adolescent in light of child psychology.
\end{abstract}

Keywords: Adolescence, innocence, experience, the human psyche, child psychology

\section{Introduction}

In Indian English literature, many writers attempt to voice out for social issues through their novels. Among them, Ruskin Bond is a notable writer who concentrates on the well-being of society by writing about children and youngsters for children and adults. He avoids using the imaginary concept as themes for his novels. The focal point of his novels is the reality-based subject which is mandatory for life. He precisely chooses the characters for his novels specifically the protagonist and antagonist characters. The antagonist in his novels cannot be labeled as a bad one alike his protagonist is not purely a spiritual soul. They react according to the people around them and the situation they live in. The adolescence phase is a period between childhood and adulthood also a distinctive segment for mental and physical growth. According to the Cambridge Dictionary, Adolescence is "the period of time in a person's life when they are developing into an adult" (Cambridge Dictionary, 1996). In this adolescence phase, an individual will find emotional development, physical development, intellectual development, social development, and moral development. Physical development consists of changes in the body like growth all over the body whereas intellectual development brings the growth in mental abilities. An individual develops his personality as the result of stimulation is called emotional development. Social development leads the individual to mingle with the family and the people outside of it that teaches them what society is. According to children, religion is not something to believe in. after the moral development, adolescent starts to believe in religion as they follow the morals for being in society.

\section{Discussion}

Ruskin Bond's Protagonists like Rusty and Somi in "The Room on the Roof", Suri and Arun in "Delhi is not Far", Ruth in "A Flight of pigeons", Kishen in "Vagrants in the Valley" are in their adolescence phase. They are similar in their characteristics like bravery, falling in love, infatuation, innocence, passion, an attraction for the opposite sex and career-oriented. Through the characters and their role in the novels, the world of adolescents is revealed.

In his first novel "The Room on the Roof", many adolescent characters are supporting each other. This novel is written by Bond when he was in his adolescence phase. It is one of the novels which effectively indicate the adolescents' psychology. On the other hand, it deals with the mind-set of Indian society and the British colony. British people like Mr. Harrison wants to grow their child as an English man even when they are settled in India. With the British attitude, Mr.Harrison instructs Rusty not to mingle with Indians and tells him to be with his British neighbors. But Rusty's adolescent world doesn't have any connection with colonization. He feels completely free to mingle with Indians that too adolescents. Somi invites Rusty to come to Bazaar once, accepting the invitation Rusty goes to Bazaar and returns home late. At first, he scares of being returned late, later it happens regularly. The freedom and the companionship take over the fear in him. Rusty has come to a stage to face the fear for his guardian when he gets caught after the Holi Festival. Mr.Harrison is not sure how to deal with the adolescent that forces him to beat Rusty badly which awakens the emotional outbreak of Rusty.

"With one hand still twisting the collar, the boy slapped his guardian's face. Mad with the pain in his own face, Rusty hit the man again and again, wildly and awkwardly, but with the giddy thrill of knowing he could do it: he 
was a child no longer, he was nearly seventeen, he was a man. He could inflict pain that was a wonderful discovery; there was a power in his body - a devil or a god - and he gained confidence in his power; and he was a man!" (39)

Rusty's decision to leave Mr. Harrison house is the next level of transition in his life from a helpless boy to the matured adulthood When Rusty stands independent financially to lead his life, he faces many difficulties still chooses to live liberally not under the control of Mr.Harrison. That is how the adolescents make learn out of the situation and take responsibility on their own. Rusty mentions himself as

"I do not want to rot like the mangoes at the end of the season, or burn out like the sun at the end of the day. I cannot live like the gardener, the cook and the water-carrier, doing the same task every day of my life. I am not interested in today, I want tomorrow. I cannot live in this same small room all my life, with a family of lizards, living in other people's homes and never having one of my own. I have to break away. I want to be either somebody or nobody. I don't want to be anybody." (105)

According to psychologists Cole and Hall (1970), adolescents experience these changes during their adolescence phase, flexibility to the society, independence, selecting their career, emotional control and financial independence.

As described by Cole and Hall, Rusty gets a chance to live with his friend Somi at his house but he chooses to stand financially independent. Getting attracted by the beauty of Mrs. Kapoor, Rusty falls for her knowing that she is the mother of a young boy Kishen. As the adolescent is in the need of basic requirements like shelter, food, education, sex, love and adventure, Rusty expresses his love to Mrs. Kapoor by kissing her. This relationship does not last long, she meets an accident and died. Mr.Kapoor remarries a young woman and left Kishen all alone that is when Rusty takes responsibility as a brother to take care of Kishen.

"Vagrants in the Valley" is a sequel to the previous novel "The Room on the Roof". "Vagrants in the Valley" deals with the adolescents Rusty, Kishen, Devinder, Sudheer and Hathi. Here, they have no roof to stay under and being wanderers is the only option they have. During their journey to nowhere, Devinder, Sudheer and Hathi help them to live. Both can understand the pleasure of companionship in the absence of care and shelter. Kishen is comfortable as far as being with Rusty. Kishen is found by her aunt and taken to her conventional home yet he meets Rusty often in the abandoned church. Devinder readily gives his hand to Rusty helping to find his aunt. Sudheer collects funds from his girlfriends and gives them to Rusty to help to find his aunt. Rusty's aunt offers him to live in her house and to take care of her.

"You are old enough to look after me,' she said putting her hand on his. 'Let us be burdens on each other. I am lonely, sometimes. I know you have friends, but they cannot care for you if you are sick or in trouble. You have no parents. I have no children. It is as simple as that" (193)

Rusty ignores the invitation since he has to travel a long way to reach his destination. He knows that he could not spare for Kishen's living when he has only little to meet his expenses but Rusty manages with the little he has. Aware of Rusty's condition, Kishen thinks to save Rusty from the burden. Rusty could have sent Kishen to steal things and money since Kishen wanted. Rusty a responsible adolescent does not let Kishen do that. He shows the moral way to live in the world. Like Rusty, Devinder an adolescent boy who wants to stand on his own for his living sells some fancy things to study and live. Optimism, ambition and dreams are the major elements in this novel. At the end of the novel, Rusty decides to go to England to find his dream fulfilled. The search for life begins in this novel after stimulating by the external factors of life. The hunger for knowing himself or the world around him is the point to rebuild his life.

Bond describes the struggle of a young boy Arun in the novel "Delhi is not far". Arun is an Urdu writer who hardly earns by writing. With the empty pocket, he dreams to achieve a high zone in his literary career. Suraj, a homeless orphan boy and a friend of Arun live with him. Even though they are matured enough to handle all the situations of their life alone, they long for friendship with Kamala a prostitute living near. In this novel, the characters like Deep Chand, Aziz and Seth Govind have dreams to achieve and they plan to step ahead in their career. Being younger than others in the novel, Arun dreams equally to achieve in his literary career. From the beginning of his career, Arun tries to write a blockbuster novel. He remains a writer despite the low income and poor life. He has options to select some other career to earn better. Thinking to do what he likes or the love for passion leads him to believe in a literary career. When he does not have a decent costume to wear for an interview, kamala gives him a shirt to attend the interview. Though selected for an editor job in a company for a three hundred rupees salary, he invited kamala and Suraj to come to Delhi with him. But kamala declines the offer on the point of taking care of her family and husband. Considering her point, Arun tells her to come wherever she wants.

Intently, taking accountability for Suraj, Arun takes Suraj Delhi along with him. The bond beyond lineage and blood, learning the world without having no parenthood, love and care they possess is the instinct layers of adolescents psyche.

Similar to other novels, Bond's protagonist will not think to get success alone, they will take their companions to settle in a better way. In "The Room on the Roof" and "Vagrants in the valley", Rusty takes care of Kishen and Somi takes care of Rusty. In "Delhi is not Far", Arun takes care of Suraj, the adolescent characters mentioned in Bond's novels have no other relationship except friendship but they wholeheartedly support their friends to achieve in their life. It is proven that the adolescence phase is a stage of emotional development and intellectual development where the adolescents react more positively than any other phase of life. They also care for others' well-being. 
In the novel "A Flight of Pigeons", Ruth is different from the other protagonists of Ruskin Bond. Because of the gender difference of adolescence mention here. The growth of an individual is different from other individuals. When a boy reaches adolescence, the growth brings changes according to gender. This novel is narrated from the perception of a thirteen-year-old girl Ruth. As Ruth is a female, she grows more feminine in this phase. She does not want to choose her career nor achieve her dreams actually there are no dreams of her indicated in this novel.

In the Rebellion of 1857, Mariam loses her husband and her family is taken to hide somewhere by Ramjimal a friend of that family. Mariam and her family are a contemplation of British rulers. Javed Khan finds out the Mariam family hiding in Ramjimal's house and brings them to his house. Javed Khan asks Mariam for her daughter even though he is married and he is not intended to know Ruth's wish of getting married. He has to get permission from the girl's family to marry her. He keeps getting rejected by Mariam telling illogical reasons. Mariam does not want her thirteen-year daughter to marry a man nor spoil the life of another woman. At last, Mariam proposes Javed she can give her daughter if the British could not break the rebellion. Unlike Javed's wish, the rebellion is started crushing.

Javed Khan wants to meet Ruth for one last time. When Mariam hesitates to bring her in front of him, Ruth steps in to see him as she decides to do what she desires. That is the moment and the only bold attempt she made to host her intention.

"He gazed at me in silence for about a minute, and for the first time I did not take my eyes away from his; then without a smile or a word, he turned away and mounted his horse and rode away into the night." (124)

Ruth learns to keep quiet not to express her idea and wish in front of people throughout the novel. Mariam wants her daughter not to marry Javed while he wants to marry her. There is no part of her telling her wish. Ruth is a passive listener who is reticent to reveal her desire whether she wants it to happen or not.

\section{Conclusion}

Henceforth, Ruskin Bond is a creator of adolescent characters following the phase factors. This paper attempts to present the role of adolescence in the novels of Bond. Analyzing these novels, it is understandable that Bond constructively handles adolescent characters. Transformations that happens in the adolescence phase is the result of mental and physical development. It is known that adolescents need help from the people around, family and society when they are growing up. The social, intellectual and moral development is possible only on the corporation of others around them. Bond cleverly noted in his novels that adolescents help each other when they are growing up also the help they get from other characters acclaimed in their future. Bond novels serve readers to understand the nature of adolescence.

\section{References:}

1. Bond, Ruskin. "The Room on the Roof”, Classic Ruskin Bond. Penguin Books, New Delhi, 2010

2. Bond, Ruskin. Vagrants in the Valley. Classic Ruskin Bond, Penguin Books, New Delhi, 2010

3. Bond, Ruskin. A Flight of Pigeons. Penguin Books, 2007.

4. Bond, Ruskin. Scenes From a Writer"s Life. Penguin Books, New Delhi, 1997.

5. Bond, Ruskin. Delhi is Not Far. Penguin Books New Delhi, 2017.

6. Cole, Luella, and Irma Nelson Hall. Psychology of Adolescence. Holt, Rinehart and Winston, 1970.

7. Vale, David, et al. The Cambridge Dictionary. Cambridge University Press, 1996. 